\title{
Spiritual Care Nurse To Patient With Breast Cancer At Last Stage
}

\author{
Nurul Rezki Anisa ${ }^{1 *}$, Kadek Ayu Erika ${ }^{2}$, Rini Rachmawaty ${ }^{3}$ \\ ${ }^{1}$ Lecturer of Surgical Medical Nursing, Nursing Department, STIKes Nani Hasanuddin, Makassar \\ ${ }^{2,3}$ Lecturer of Master of Nursing, Nursing Faculty, Hasanuddin University, Makassar \\ *Email: renisa.cok@gmail.com
}

\begin{abstract}
Background: spiritual care is one of the interventions that can be applied in hospital services to the patients with near death conditions as mentioned in the Nursing Intervention Classification. Aim this study is to describe spiritual care nurse to patient with last stage breast cancer. Methods: A literature review were obtained from PubMed, and google scholar using the keywords breast cancer AND palliative care and breast cancer AND spiritual care by adding filters: the type of article is Full text with Randomized Controlled Trial, published in the last 5 years, written in English and Indonesian, human studied, specific to cancer, and are in the category of nursing journals and medline. Results: According to a review of previews studies, spiritual care is effective to treat mental problems, such as anxiety, stress, even depression as it affects patients to solemnly accept their health condition including the complications in positive ways. Therefore, patients receiving spiritual care will be more adhere to their medical treatments, will have lack of emotional disturbances and substance abuse, have greater social support, will be more frequent performing their health behavior and have a longer period of survival.Conclusion: Spiritual care is highly needed in managing care, especially for those who have serious and life-threatening diseases. Assessing and addressing the spiritual needs of patients is associated with greater satisfaction on service, better quality of life, less depression, less unnecessary health services, and better nurse-patient relationships.
\end{abstract}

Keywords: breast cancer, oncology nurses, spiritual care

\section{INTRODUCTION}

Cancer is one of the terminal diseases that causes highest death every year (Health Ministry of Indonesia, 2015; Globocan, 2012). According to an estimate from the World Health Organization (2016), cancer causes more deaths than any coronary heart disease or stroke. Breast cancer has the highest percentage globally of new cases of cancer after controlling by age, which is $43.3 \%$, and the percentage of death after controlled by age of $12.9 \%$ (Globocan, 2012).

In Indonesia, breast cancer is the second highest cancer following cervical cancer among the females (Riskesdas, 2013). In South Sulawesi, it is ranked at fourth place among the 34 provinces with the highest number of breast cancer patients in Indonesia (Riskesdas, 2013). Often, breast cancers are found incidentally and mostly at an advanced stage due to the unhealthy symptoms are very rarely felt in the early stages (Black \& Hawks, 2014). Many patients visit and check themselves in the health service at the time the symptoms begin to be felt. Mostly the cancer patients with end stage will experience more psychological stress after knowing the diagnostic.

It is commonly known that the prognosis of the breast cancer is poor, and so is the complication (Shahriari et al., 2017). In addition, the patients with breast cancer do suffer negative side effects on - physical function and quality of life related to the etreatments 
process (Olver, Eliott, \& Koczwara, 2014). The treatment of the disease such as chemotherapy affects to physical condition that are fatigue, nausea, vomiting, loss of appetite, performance changes, even insomnia and also to the mental such as stress and depression, even social pressures causing body function decreased, sexuality problems, body-image disturbance, lack of confidence, angry, severity of physical and psychological function changes (Adeola et al., 2015; Donovan, Thompson, \& Jacobsen, 2012; Kim et al., 2012; Zainal, Nikjaafar, Baharudin, Sabki, \& Guan Ng, 2013).

Physical and psychosocial disturbances at the first year being diagnosed and undergoing chemotherapy are fatigue, anxiety, stress, depression, nausea and vomiting, no desire to sexuality, decreased quality of life, even aggressive behaviors that damaging lives. The fears of the treatment side effects, the instruction to take the operation of breast removal, and the cost of the treatment and limitations to access hospital affect the patient's acceptance of the disease.

In terminal conditions and towards the end of life with physical complaints and emotional disturbances such as stress, anxiety or even depression, spiritual needs become important for patients (Baldacchino, 2015). Jafari, Zamani, \& Farajzadegan (2013) stated that it is important to meet the spiritual needs od the patient with the terminal diseases to find meaning and purpose in life, and raise hopes for recovery. Based on the National Consensus Project (2013), one of the national service quality guidelines for chronic and palliative diseases is spiritual care (Anisa, Erika,
Rachmawaty, 2018). It has domain five (spiritual, religious, and the existence of aspects of care), including respect and recognize the religious and spiritual needs of cancer patients. Some examples in spiritual support activities are praying therapy, accompanying patients by giving care, support, empathy, therapeutic communication, and appropriate nformation to religious leaders (Bulechek et.al., 2013).

Spiritual care is one of the care strategies and appropriate intervention towards the palliative conditions or near death in the hospital and is written in the Nursing Intervention Classification. Thus, nurses working in the oncology department have important responsibility in providing spiritual care for patients with terminal illness and to help them to cope with health and crisis situation (Sansó et al., 2015).

\section{METHODS}

It is a literature review. The articles selected in this literature review were obtained from PubMed, and google scholar using the keywords breast cancer AND palliative care and breast cancer AND spiritual care by adding filters: the type of article is Full text with Randomized Controlled Trial, published in the last 5 years, written in English and Indonesian, human studied, specific to cancer, and are in the category of nursing journals and MEDLINE. Total overall articles that researchers get from Google Scholar and PubMed are 446 articles. The removal of several articles is done by reviewing articles that have something in common (in the title, abstract, preliminary content). Articles which are irrelevant and do not fit the criteria are 
discarded. The final step is the review of articles, namely by considering the variables discussed in the articles obtained. The final article chosen was an article that focused on discussing spiritual care in end-stage breast cancer patients as palliative care. The final results obtained are 6 articles that meet the criteria (Figure 1).

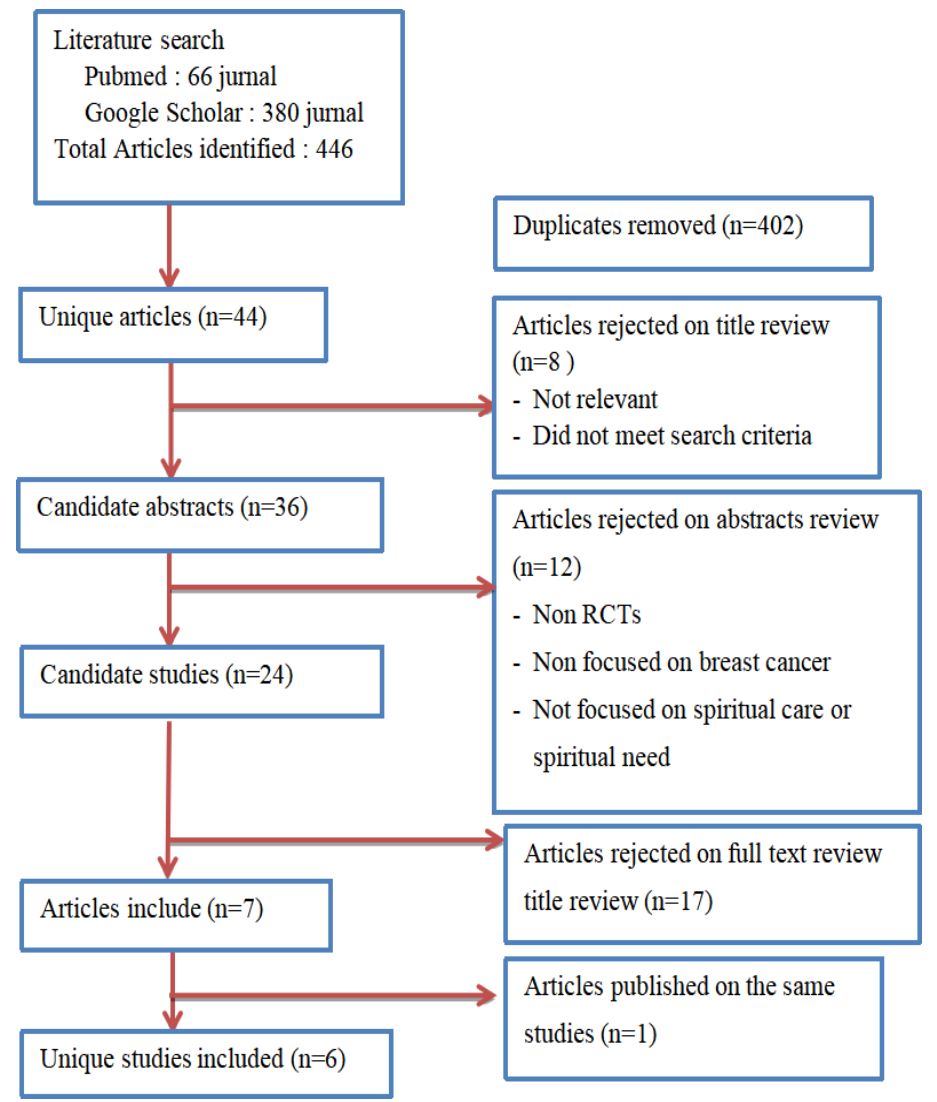

Figure 1. Flowchart Gathering References

\section{RESULTS}

End-stage cancer is a disease that requires palliative care. It has poor prognosis and complications in the process of the disease, specially at the last stage. In addition, there are some impacts negatively on physical function and quality of life to the patients undergoing chemotherapy (Olver, Eliott, \& Koczwara, 2014; Shahriari et al., 2017). The reaction of patients with late stage diagnostic cancer will be disrupted by physical and psychological stress. Therefore, the main treatment of palliative care are identification of physical and emotional symptoms, and assessment the spiritual condition. The spiritual, religious and existential needs are part of the domains and recommendations from the National Consensus Panel Guidelines in palliative care (table 1).

Spiritual needs are a priority for patients with chronic illness and towards the end of life, especially diseases that worsen physical and mental conditions that cause anxiety, stress, and even depression (Baldacchino, 2015). Meeting spiritual needs can increase hope (Jafari, 
Zamani, \& Farajzadegan, 2013). Hope is one of the important elements for patients to survive with a diagnosis of end-stage cancer (Tabrizi, Radfar, and Taei, 2016). Therefore, spiritual care is one of the standard components to fulfill the quality service that has been created in the form of palliative care guidelines (National Consensus Project, 2013).

Based on the study of preview researches, spiritual treatments are effective for dealing with emotional disturbances and have an effect on accepting a sick condition with the appearance changes or other symptoms caused by the effects of cancer treatment (Anisa et.al., 2018). Spiritual involvement is known having the positive effect to patient welfare, decrease the emotional disturbances, decrease the substance abuse, better social support, increase health behaviors and life spans.

Table 1. Domain and Palliative Care Recommendations (National Consensus Panel Guidelines)

\begin{tabular}{|c|c|}
\hline Domain & Key Recommendation \\
\hline $\begin{array}{l}\text { Treatment Structure and } \\
\text { Process }\end{array}$ & $\begin{array}{l}\text { Interdisciplinary team, comprehensive interdisciplinary assessment, } \\
\text { education and training; relationship to the hospital treatment } \\
\text { program }\end{array}$ \\
\hline Physical aspects of care & Pain and other symptoms are managed using best practices \\
\hline Psychological and & Psychological and psychiatric problems are assessed and managed; \\
\hline Psychiatric Care Aspects & grief and sorrow programs are available for patients and families \\
\hline Social aspects of care & $\begin{array}{l}\text { Social aspects of care Interdisciplinary social assessment with } \\
\text { appropriate treatment plans; referral to the appropriate service }\end{array}$ \\
\hline Spiritual and Religious Care & $\begin{array}{l}\text { Spiritual worries are valued and dealt with; relationships with } \\
\text { communities and spiritual or religious resources are provided as } \\
\text { appropriate }\end{array}$ \\
\hline Cultural aspects of care & $\begin{array}{l}\text { The special needs of the patient and family culture are assessed and } \\
\text { addressed; recruitment and recruitment practices reflect the cultural } \\
\text { diversity of the community }\end{array}$ \\
\hline Treatment of dying patients & $\begin{array}{l}\text { Signs and symptoms of impending death are recognized and } \\
\text { communicated; Hospital referral is recommended when the patient } \\
\text { is eligible }\end{array}$ \\
\hline $\begin{array}{l}\text { Ethical and Legal Aspects of } \\
\text { Care }\end{array}$ & $\begin{array}{l}\text { Patient goals, preferences, and choices form the basis for the } \\
\text { treatment plan; the team has knowledge of relevant federal and state } \\
\text { laws and regulations }\end{array}$ \\
\hline
\end{tabular}

\section{DISCUSSIONS}

The majority of patients with breast cancer at the last stage or serious illnesses want to convey and communicate their spirituality to their health care providers. Spiritual worries are common to them. Nurses are needed to give spiritual care in special circumstances and present in patients' life-threatening situation. Nurse can help to find means for patients who face worse conditions towards the end of life (Sanso et al., 2015). Nurses are expected to meet these spiritual needs because nurses are always present and accompanying patients in 24 hours. Therefore, nurses are important health professionals for patients who are vulnerable in the care process (LeePoy, Stewart, Ryan, \& Brown, 2016).

However, meeting the spiritual needs of patients is still very rare which may be caused by many factors, including the unavailability of resources and the lack of care of health workers for the spiritual needs of 
patients. This is supported by less than $50 \%$ of health service providers believing that it is their role to overcome these concerns, and only a small proportion of patients state their spiritual needs are met (El Nawawi, Balboni, Balboni, 2012; Rodin, Balboni, Mitchell, Smith, VanderWeele, Balboni, 2015). Thus, the sickest patients expect their health care team to overcome spiritual problems as part of their treatment program (Winkelman, Lauderdale, Balboni et.al., 2011).

Many studies have shown that spirituality and religious practice are important and have good results in patients with serious illnesses. Winkelman et al. (2011) conducted observational studies and found that quality of life was more likely to have significantly worse psychological outcomes in patients with cancer who had unresolved spiritual problems than those whose spiritual concerns were addressed. Furthermore, a multisite cohort study with 343 end-stage cancer patients found that patients whose spiritual needs were supported attended a hospital treatment program and some obtained useful interventions near death than those whose spiritual needs were not met (Balboni, Vanderwerker, Blok, 2007).

Spiritual support from health care teams or religious communities is associated with higher quality of life scores (Balboni et. Al, 2010). It is well known that giving the spiritual care has many of the effectiveness . However, the mechanism by which spiritual fulfillment influences physiological outcomes is still not well explained.

Treatment of advanced stage breast cancer is multidisciplinary, starting with diagnostic enforcement supported by a complete examination, to multimodality treatment with surgery, chemotherapy, radiation, or a combination of these three things (Setiati, Alwi, Sudoyo, Simadibrata, Setiyohadi, Syam; p. 2923 , 2015). Besides curative treatment, supportive medicine plays a very important role for cancer patients. Supportive treatment is a supportive treatment given to cancer patients. Supportive medicine covers all aspects of health, both physically and psychologically. Spiritual care is one part of supportive medicine.

Spiritual care is not always related to religion, but rather about topics related to personal expectations. Belief or religion is a meaning or deep understanding that affects the condition of severe illness and near death or the end of life (Setiati et al .; p. 2964, 2015). Nurses must be able to appreciate this. Based on the experiences faced in Indonesia, religious issues are important and dominant for terminal patients or near death (Setiati et al .; p. 2964, 2015).

There are many articles that reviews the effectiveness of spiritual care in health service units, as well as the importance of spiritual identification and meeting for greater welfare. A better physical health is found in religious people than nonreligious patients with the increasing of immune system in more than $50 \%$ of 25 researches; better endocrine system in almost $75 \%$ of 31 researches; improved cardiovascular function in close to $70 \%$ of 16 researches; decrease the Coronary heart disease in nearly two thirds of 19 researches; lower blood pressure in nearly $60 \%$ of 63 researches; a better prognosis of cancer in more than half of the 25 researches, 
and greater longevity in $68 \%$ of 121 researches (El Nawawi, Balboni, \& Balboni, 2012).

Those studies shows that when spiritual needs are ignores in hospital treatment, it would affect to decrease the satisfaction of service and reduce the patients' quality of life, and increase two or three times the cost of hospital services towards the palliative care (TA Balboni et al., 2013; El Nawawi et al., 2012; Jafari et al., 2013; Vilalta, Valls, Porta, \& Viñas, 2014).

\section{CONCLUSION}

Spiritual care is an appropriate therapy to physical and mental complaints for patients with end-stage breast cancer until they die. The hospital where the provision of health services for end-stage cancer patients is needed to provide competent nurses in spiritual care that able to fulfill the spiritual needs towards the terminal or palliative conditions. Research is needed to determine the mechanism by which spiritual fulfillment influences physiological outcomes.

\section{REFERENCES}

Adeola, M. T., Baird, C. L., Sands, L. P., Longoria, N., Henry, U., Nielsen, J., \& Shields, C. G. (2015). Active Despite Pain: Patient Experiences With Guided Imagery With Relaxation Compared to Planned Rest, 19(6), 649-652.

Balboni T.A., Paulk ME, Balboni MJ, et al. (2010). Provision of spiritual care to patients with advanced cancer: associations with medical care and quality of life near death. J Clin Oncol; 28: 445-52.
Balboni T.A., Vanderwerker LC, Block SD, et al. (2007). Religiousness and spiritual support among advanced cancer patients and associations with end-of-life treatment preferences and quality of life. J Clin Oncol; 25: 555-60.

Baldacchino, D. (2015). Spiritual care education of health care professionals. Religions, 594613.

Black, Joyce M., \& Hawks, Jame Hokanson. (2014). Keperawatan medikal bedah: Buku 1 manajemen klinis untuk hasil yang diharapkan. edisi 8 . Singapore: Elsevier.

Black, Joyce M., \& Hawks, Jame Hokanson. (2014). Keperawatan medikal bedah: Buku 2 manajemen klinis untuk hasil yang diharapkan. edisi 8 . Singapore: Elsevier.

Bulechek, Gloria M., Butcher, Howard K., Dochterman, Joanne M., Wagner, Cheryl M., (2013). Nurisng Intervention Classification (NIC). 6th edition. Elsevier: Oxford.

El Nawawi NM, Balboni MJ, Balboni TA. (2012). Palliative care and spiritual care: the crucial role of spiritual care in the care of patients with advanced illness. Curr Opin Support Palliat Care; 6: 269-74.

Globocan. (2012). Estimated Incidence, Mortality and Prevalence Worldwide in 2012. Retrieved 
from

http://globocan.iarc.fr/Pages/fact _sheets_cancer.aspx

Jafari, N., Zamani, A., \& Farajzadegan, Z. (2013). The effect of spiritual therapy for improving the quality of life of women with breast cancer: A randomized controlled trial, (October), 37-41. http://doi.org/10.1080/13548506. 2012.679738.

Kementerian, K. R. (2015). Situasi Global Penyakit Kanker. Buletin Jendela Data Dan Informasi Kementerian Kesehatan RI. https://doi.org/10.1007/s13398014-0173-7.2

Lee-Poy, M., Stewart, M., Ryan, B. L., \& Brown, J. B. (2016). Asking patients about their religious and spiritual beliefs Cross-sectional study of family physicians Recherche Questionner les patients sur leurs croyances religieuses et spirituelles Une étude transversale auprès de médecins de famille. Canadian Family Physician, 62, 555-561.

National Concensus Project. (2013). Clinical Practice Guidelines Palliative Care (3rd ed.). United States of America: National Consensus Project for Quality Palliative Care.

Olver, I. N., Eliott, J. A., \& Koczwara, B. (2014). A qualitative study investigating chemotherapyinduced nausea as a symptom cluster. Support Care Cancer. https://doi.org/10.1007/s00520014-2276-2
Riskesdas. (2013). Riset Kesehatan Dasar. Jakarta: Badan penelitian dan pengembangan kesehatan kementrian kesehatan RI Tahun 2013.

Rodin D, Balboni M, Mitchell C, Smith PT, VanderWeele TJ, Balboni TA. (2015). Whose role? Oncology practitioners' perceptions of their role in providing spiritual care to advanced cancer patients. Support Care Cancer (Epub ahead of print).

Sansó, N., Galiana, L., Oliver, A., Pascual, A., Sinclair, S., \& Benito, E. (2015). Palliative care professionals' inner life: the relationshipsamong awareness, self-care and compassion satisfaction and fatigue, burn out, and coping with death. Journal Pain and Symptom Management, 2(April).

http://doi.org/10.1016/j.jpainsym man.2015.02.013.This.

Setiati, S., Alwi, I., Sudoyo, A. W., Simadibrata, M., stiyohadi, B., \& Syam, A. F. (2015). Buku ajar ilmu penyakit dalam. Jakarta: InternaPublishing.

Tabrizi, F. M., Radfar, M., \& Taei, Z. (2016). Effects of supportiveexpressive discussion groups on loneliness, hope and quality of life in bbeast cancer survivors: a randomized control trial. PsychoOncology, 1057-1063.

Winkelman WD, Lauderdale K, Balboni MJ, et al. (2011). The 
116 Jurnal Terpadu Ilmu Kesehatan, Volume 9, No 1, Mei 2020, hlm 1-116

relationship of spiritual concerns to the quality of life of advanced cancer patients: preliminary findings. J Palliat Med; 14: 10228.

Zainal, N. Z., Nik-jaafar, N. R., Baharudin, A., Sabki, A., \& Guan $\mathrm{Ng}$, C. (2013). Prevalence of Depression in Breast Cancer Survivors : a Systematic Review of Observational Studies. Asian Pacific Journal of Cancer Prevention, 14, 2649-2656. 